\title{
Physiological, Growth, and Biomass Attributes in Populus deltoides L. (clones G-48 and Kranti) Influenced by Water Stress
}

\author{
Munna Singh, Aradhna Kumari, and Krishan Kumar Verma
}

\begin{abstract}
Six-week-old uniform cottonwood seedlings (clones G-48 and Kranti) were raised from stem cuttings and subjected under two different water regimes (full and half field capacity) up to 60 days under open field conditions. The higher and lower regulations of physiological responses were triggered in case these seedlings irrigated up to their full and half-field capacities. The enhanced $A$ value was observed from $13-19$ and $12-14 \mu \mathrm{mol} \mathrm{m}^{-2} \mathrm{~s}^{-1}$ in clones G-48 and Kranti after subjecting them under irrigation to the level of full field capacity. The withdrawal of irrigation to the level of half field capacity could reduce these values $(\leq 50 \%)$, significantly. The decreased $\mathrm{CO}_{2}$ assimilation during drought stress was found to be correlated with decline in transpiration, largely regulated by stomatal dynamics to restrict $\mathrm{CO}_{2}$ diffusion, which also impaired carboxylation. Upon experiencing drought, the progressive loss in maximum quantum yield of photosystem II photochemistry $(F \mathrm{v} / \mathrm{Fm})$ and $\mathrm{CO}_{2}$ assimilation was found to be correlated with the loss in transpiration in both these clones. Consequently, the study reveals that irrigation to the level of half field capacity for a period of 60 days impaired agronomic traits viz., plant height, number of leaves, leaf area expansion, specific leaf area, relative water content, biomass, and harvest index, significantly. It also concludes susceptibility of clones G-48 and Kranti toward drought in relation to plant performance (i.e., $\mathrm{CO}_{2}$ assimilation, $F \mathrm{v} / F \mathrm{~m}$, and biomass yield).

Key Words. Biomass; Cottonwood; Drought; $F \mathrm{v} / F \mathrm{~m}$; Photosynthesis; Populus deltoides L.; Transpiration.
\end{abstract}

Eastern cottonwood (Populus deltoides L.) is a native of North America and was introduced in India in 1950. India became a member of the International Poplar Commission in 1965, and constituted a National Poplar Commission with an objective to cultivate cottonwood extensively due to its high productivity, possibility of co-cultivation with crops between the rows of rice in the summer or rainy season (July-September) and wheat in the winter (November-February) through inputs of irrigation and fertilizer management in India's northern agro-climatic zones. It is one of the fast growing and commercially large-scale cultivated tree crops, getting recommended for agro-forestry these days in the foothills of northern Himalaya, especially in Himachal Pradesh, Uttarakhand, and Uttar Pradesh in India. It has also become an important agro-forestry tree species in the Indogangetic plains due to its straight stem, thin crown canopy, deciduous nature, and short-rotation with good agronomic traits (Singh 1991). The farmers have adopted its cultivation as block plantation or around field bunds, owing to its very fast growth rate (up to $48 \mathrm{~m}^{3} / \mathrm{ha}^{-1} \mathrm{yr}^{-1}$ at density of 500 stems ha $^{-1}$ ) under short-rotation period (6-7 years) with multiple uses of wood and high economic returns.

Drought stress is an important abiotic environmental factor that limits $\mathrm{CO}_{2}$ assimilation abilities and affects plant growth, productivity, and biomass (Fini et al. 2009; Akcay et al. 2010; Santos et al. 2013; Fini et al. 2013). It may also induce socioeconomic and environmental losses (Johari-Pireivatlou et al. 2010). The long-term effect of drought stress alters carbon allocation between plant organs due to decreased leaf area expansion and leaf number (Chen et al. 1997; Tschaplinski et al. 1998; Xiao et al. 2005). A decrease in specific leaf area (SLA) as an indicator of density or thickness of the leaves has often been observed with a subsequent increase in water retention due to an accentuation of the resistance to water transfer in the leaf (Niinemets 2001; Nautiyal et al. 2002). The loss in carbon assimilation occurs due to impaired stomatal conductance (Singh et al. 1996; Maier 1998; Fukuzawa et al. 2012). The drought tolerance (i.e., an ability to maintain physiological process at declining leaf water potential) and drought avoidance (i.e., an ability to avoid the decline in leaf water potential during drought) may extend drought resistance in plants (Levitt 1980; Poorter and Markesteijn 2008). The cottonwood has shown temperature optima ranging from $20^{\circ} \mathrm{C}-30^{\circ} \mathrm{C}$ depending upon its growing seasons, was also found to be more prone for water, saline, and temperature stress in the planting year (Singh et al. 1996; Singh et al. 1999), while short-term dynamic waterlogging was found to be nearly non-vulnerable. Physiological responses, such as $\mathrm{CO}_{2}$ assimilation $(A)$, transpiration (E), stomatal conductance (gs), maximum quantum yield of PS II photochemistry $\left(F_{\mathrm{V}} / F \mathrm{~m}\right)$, and other interrelated bio-chemical activities were found to be associated with plant performance, productivity, and biomass yield (Singh et al. 1996; Singh and Chaturvedi 1997; Singh et al. 1999; Fukuzawa et al. 2012; Fini et al. 2013). The maximum quantum yield of PS II photochemistry and plant productivity are dependent on genotype, species, climate, soils, and plants nutrient status (Fini et al. 2013). 
Besides food and fiber requirements, timber and wood are also needed by the human societies globally these days. The forest cover of India is $21.05 \%$, which is lower compared to developed nations. Thus, keeping the large-scale utilities of cottonwood in view, the current study is focused on extending its cultivation areas in other nearby agro-climatic zones, which often experience less rain showers, and could not sustain adequate moisture content in the soil. These sites are also influenced by dry air (lower relative humidity) and higher temperature $\left(35^{\circ} \mathrm{C}-45^{\circ} \mathrm{C}\right)$. Hence, the aim was to reveal growth and developmental attributes in cottonwood influenced by irrigation levels (i.e., up to full and half field capacities) to correlate plant performance and productivity or biomass yield integrated with sustainability of agro-socio economy.

\section{MATERIALS AND METHODS}

\section{Plant and Growth Conditions}

Cottonwood is a temperate in origin and may grow well upon maintaining soil moisture content. The experiment was conducted at the Department of Plant Physiology, College of Basic Science and Humanities (CBSH), G.B. Pant University of Agriculture and Technology, Pantnagar, Uttarakhand (India). Cottonwood clones [i.e., G 48 and Kranti (stem cuttings)] were purchased from WIMCO seedlings (Pvt.) Ltd. Bagwala (Kashipur Road), Rudrapur, Udham Singh Nagar (Uttarakhand). These clones are highly preferred by the farmers for large-scale plantation- cultivation. The cuttings, having uniform diameter and length $(18-20 \mathrm{~cm})$, were planted in poly-bags $(2 \mathrm{~kg})$ to allow sprouting for four weeks. Afterwards these seedlings were transplanted in earthen pots $(30 \mathrm{~cm}$ diameter, $30 \mathrm{~cm}$ depth) filled with fertile soil (silty clay loam, $\mathrm{pH} 7.1$, organic carbon$0.86 \%$ and $\mathrm{N}, \mathrm{P}, \mathrm{K}-245,35.5$ and $172 \mathrm{~kg} \mathrm{ha}^{-1}$ ) for a period of two weeks to allow their establishment. Uniformly grown cottonwood seedlings were chosen for subjecting them under two irrigation water regimes (i.e., up to full and half field capacities).

Thus, two soil moisture levels were maintained through precise application of water in earthen pots. The control set of plants were irrigated to the level of full field capacity $\left(1 \mathrm{~L} \mathrm{day}^{-1}\right)$, while half field capacity $\left(0.5 \mathrm{~L} \mathrm{day}^{-1}\right)$ was maintained to impose water stress over growing seedlings throughout and up to a period of 60 days. These pots were covered by plastic to prevent the intrusion of rain water. The growth, physiological and biomass responses of these seedlings were measured at specific time intervals, as indicated.

\section{Field Capacity}

The field capacity was calculated by applying the formula for volume of frustum of right circular cone. It was also calculated by recording incremental diameter of the container at different heights [i.e., 0 (base), 5, 10, 15, 20, 25, and $30 \mathrm{~cm}$ (from bottom to top)]. These calculation methods have provided the container's volume, which was nearly the same [i.e., $12.4 \mathrm{~cm}^{3}(12.4$ L)]. The moist soil from an agricultural field was extracted and placed in these containers (earthen pots) up to the height of 20 $\mathrm{cm}$ only. The field capacity of these containers was calculated as:

(i) The volume of water required for saturating filled soil in the containers $=1475 \mathrm{ml}$.

(ii) The volume of water drained out after 24 hours from the containers $=475 \mathrm{ml}$. (iii) The volume of water retained after removal of gravitational water $=1000 \mathrm{ml}$

\section{Photosynthetic and Chlorophyll Fluorescence Measurement}

Photosynthetic measurements were made by using CIRAS-1, IRGA, portable photosynthesis system (PP system, Amesbury, Massachusetts, U.S.). The completely expanded leaves (6th8th position) were used for the observations under natural sunlight $\left(\sim 1500 \mu \mathrm{mol} \mathrm{m} \mathrm{m}^{-2} \mathrm{~s}^{-1}\right)$ between 8:00-10:00 a.m. to avoid high temperature and low humidity. The maximum quantum yield of PS II photochemistry was obtained through chlorophyll a fluorescence on the same leaf for which $\mathrm{CO}_{2}$ assimilation was evaluated. The measurements of maximum quantum yield of PS II photochemistry $(F \mathrm{v} / F \mathrm{~m})$ were determined, after the leaves were adapted to the dark (30 min) by using Plant Efficiency Analyzer (Handy PEA, Hansatech, King Lynn, UK).

\section{Growth Parameters}

At the end of the experiment (60 days after treatment), plant height and number of leaves were monitored followed by a destructive harvest. Ten seedlings of each clone (G-48 and Kranti) from control and treatment were randomly sampled. Leaf area was measured using a Leaf Area Meter (CI-203-CID, U.S.). Specific leaf area of the whole plant (SLA) $\left(\mathrm{cm}^{2} \mathrm{~g}^{-1}\right)$ was calculated according to Beadle (1993). The relative leaf water content (RWC) was determined as $100 \times(\mathrm{FM}-\mathrm{DM}) /(\mathrm{TM}-\mathrm{DM})$, where FM is a fresh mass, TM is turgid mass after re-hydrating the leaves ( 24 hours, $25^{\circ} \mathrm{C}$, dark), and DM is dry mass after oven drying the leaves $\left(68^{\circ} \mathrm{C}, 48\right.$ hours $)$. Dry weight was obtained by weighing the plant material after drying to achieve the constant dry mass. The harvest index was calculated according to Michael et al. (1988) by harvesting at least 10 seedlings from each set of the treatment.

Data management and statistical analysis were performed using SPSS software (SPSS, Chicago, Illinois, U.S.). Means were expressed with their standard error $( \pm \mathrm{SE})$ and compared by ANOVA. All statistical tests were considered significant at $P \leq 0.05$.

\section{RESULTS}

The influence of two different irrigation regimes was assessed on $\mathrm{CO}_{2}$ assimilation $(A)$, transpiration $(\mathrm{E})$, and maximum quantum yield of PS II photochemistry $(F \mathrm{~V} / F \mathrm{~m})$ in cottonwood clones (i.e., G-48 and Kranti). The expression of higher and lower levels of physiological responses occurred when these plants were irrigated up to their full and half field capacities, respectively. A temporal up-regulation for $A$ occurred in these clones in case irrigated up to full field capacity. Accordingly, upon maintaining irrigation up to field capacity to 60 days, clones G-48 and Kranti expressed progressively enhanced $A$ values from 13 to $19 \mu \mathrm{mol}$ $\mathrm{m}^{-2} \mathrm{~s}^{-1}$ and 12 to $14 \mu \mathrm{mol} \mathrm{m} \mathrm{m}^{-2} \mathrm{~s}^{-1}$, respectively. However, withdrawal of irrigation to half field capacity in these clones viz. G-48 and Kranti resulted in significant decline in $A$ from 13 to $6 \mu \mathrm{mol} \mathrm{m}^{-2} \mathrm{~s}^{-1}$, and 12 to $5 \mu \mathrm{mol} \mathrm{m} \mathrm{m}^{-2} \mathrm{~s}^{-1}$, respectively (Figure $1 \mathrm{~A}, \mathrm{a}$ ). The transpiration (E) was found to be almost identical for both clones $(\sim 3 \mu \mathrm{mol}$ $\left.\mathrm{m}^{-2} \mathrm{~s}^{-1}\right)$ upon irrigating them up to field capacity, while providing irrigation up to half field capacity reduced to the level of $\sim 1$ $\mu \mathrm{mol} \mathrm{m} \mathrm{s}^{-1}$ (Figure 1B, b). The improved $P_{\mathrm{N}} /$ E trends (intrinsic water use efficiency) were found always higher than the con- 
Table 1. Growth parameters of eastern cottonwood (Populus deltoides L.) (clones: G-48 and Kranti) seedlings grown under two water regimes ( $100 \%$ and $50 \%$ of field capacity) for a period of 60 days. Observations were made after terminating the treatment by harvesting plant parts. Each data is the mean value of at least ten independent replications with S.E. ( \pm ).

\begin{tabular}{|c|c|c|c|c|c|c|}
\hline \multirow[t]{2}{*}{ Parameters } & \multicolumn{3}{|l|}{ G-48 } & \multicolumn{3}{|l|}{ Kranti } \\
\hline & Control & Stressed & Loss $(\%)$ & Control & Stressed & Loss $(\%)$ \\
\hline Height $(\mathrm{cm})$ & $103.3 \pm 5.1$ & $52.7 \pm 2.2$ & 48.98 & $78.8 \pm 1.8$ & $36 \pm 1.1$ & 54.31 \\
\hline Number of leaves & $24 \pm 1.4$ & $7 \pm 0.5$ & 70.83 & $21 \pm 1.1$ & $6 \pm 0.7$ & 71.43 \\
\hline Leaf area $\left(\mathrm{cm}^{2}\right)$ & $135.5 \pm 7$ & $57.3 \pm 1.7$ & 57.71 & $71.8 \pm 1.9$ & $34.1 \pm 1.3$ & 52.51 \\
\hline SLA $\left(\mathrm{cm}^{2} \mathrm{~g}^{-1}\right)$ & $101.2 \pm 6.1$ & $95 \pm 2.5$ & 7.11 & $98.3 \pm 2.1$ & $91 \pm 2.1$ & 7.43 \\
\hline $\operatorname{RWC}(\%)$ & $93.5 \pm 3.6$ & $91.3 \pm 3.3$ & 2.35 & $91.4 \pm 2.4$ & $88.8 \pm 1.2$ & 2.84 \\
\hline Total biomass (g) & $59.48 \pm 3.1$ & $27.72 \pm 1.3$ & 53.40 & $34.29 \pm 1.7$ & $15.76 \pm 0.9$ & 54.04 \\
\hline Harvest index & $0.99 \pm 0.02$ & $0.52 \pm 0.01$ & 47.47 & $0.74 \pm 0.01$ & $0.34 \pm 0.01$ & 54.05 \\
\hline
\end{tabular}

Note: SLA = specific leaf area, RWC = relative leaf water content.

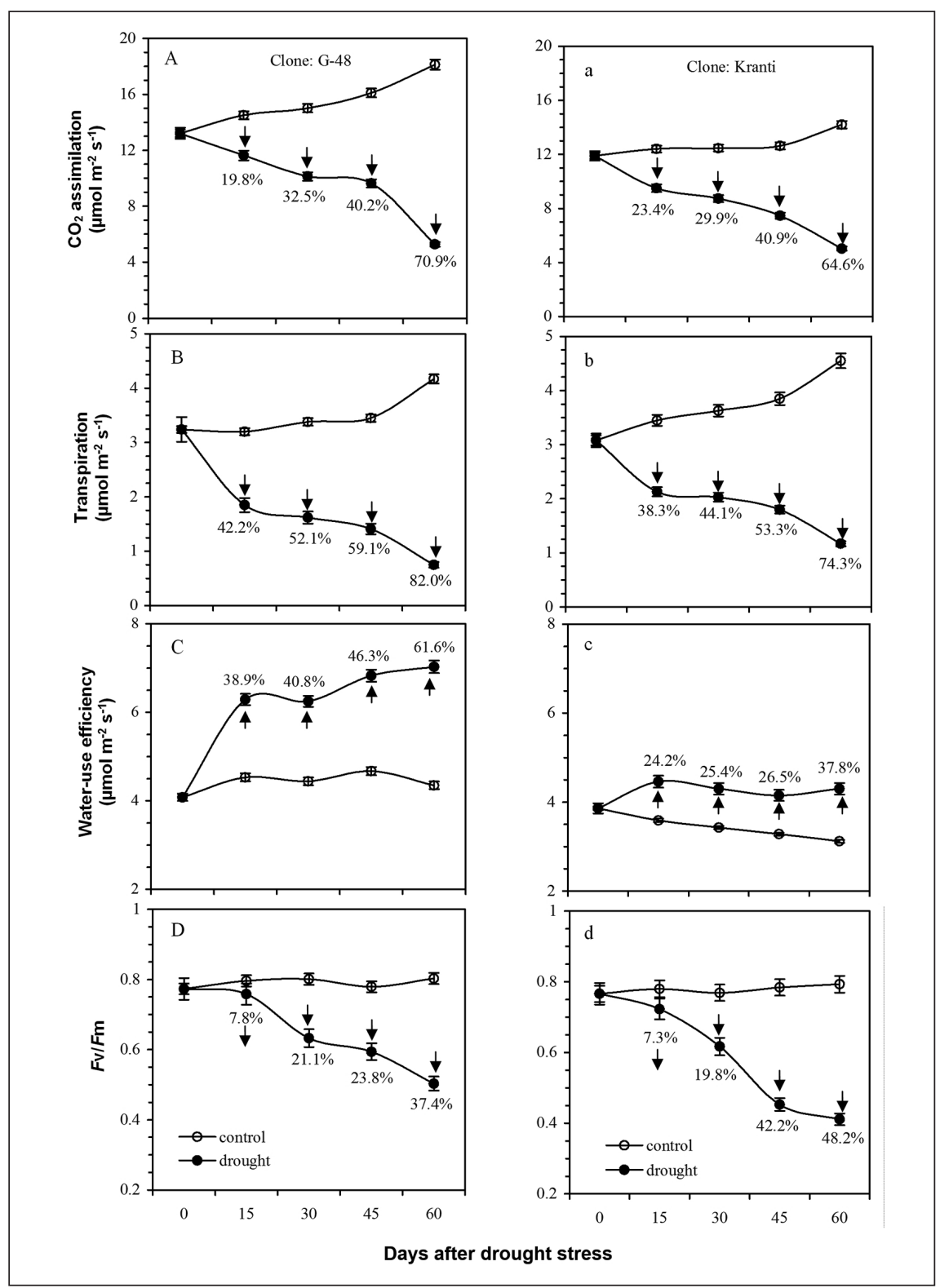

Figure 1. Influence of drought on physiological responses in cottonwood. $\mathrm{CO}_{2}$ assimilation $(A, a)$, transpiration $(B, b)$, intrinsic water use efficiency $(C, C)$, and maximum quantum yield of photosystem II photochemistry $(D, d)$. The drought was maintained by using two irrigation water regimes (100\% and $50 \%$ of $\mathrm{FC})$. Each data is the mean value of at least ten independent replications with S.E. ( \pm ). trol plants in both clones (Figure $1 \mathrm{C}, \mathrm{c}$ ). The maximum quantum yield of PS II photochemistry $(F \mathrm{v} / F \mathrm{~m})$ was sustained throughout the experiment (until 60 days) in control seedlings. The expression of nearly same $F \mathrm{v} /$ $F \mathrm{~m}$ values $(\sim 0.76)$ was shown by both clones throughout in case irrigated up to full field capacity. It was found impaired from 0.76 to $0.42(\leq 50 \%)$ upon irrigating these clones up to the level of half field capacity for a period of 60 days (Figure 1D, d). The effect of drought stress on agronomic traits in these clones was also measured (Table 1). The findings indicate that irrigation up to the level of half field capacity for a period of 60 days significantly affected plant height, leaf number, leaf area expansion, specific leaf area (SLA), relative water content (RWC), plant performance as diagnosed through impaired maximum quantum yield of PS II photochemistry, $\mathrm{CO}_{2}$ assimilation, transpiration, stomatal dynamics, total biomass, and harvest index.

\section{DISCUSSION}

Populus deltoides L. plants are efficient for doing $\mathrm{CO}_{2}$ assimilation and related characteristics to enhance plant productivity and biomass yield upon experiencing adequate soil-water availability with temperature optima $\sim 25^{\circ} \mathrm{C}$ during the rainy season (JulyAugust) in north India (Singh et al. 1996; Singh et al. 1999). However, withdrawing irrigation up to the level of half field capacity for 60 days triggered significant loss in $\mathrm{CO}_{2}$ assimilation in these clones [i.e., G-48 (70\%) and Kranti $(65 \%)$ ], as compared to fully irrigated plants. Similarly, the values of transpiration were also found to be declined to the level of ca. $82 \%$ and $74 \%$ in clones G-48 and Kranti, respectively. There are several reports that underline stomatal limitation for the operation of photosynthesis under stress (Chaves 1991; Lawlor 1995; Singh et al. 1996; Zlatev and Yordanov 2004; Silva et al. 2010; Fukuzawa et al. 2012; Verma et al. 2012; Fini 
et al. 2013; Santos et al. 2013). Thus, the progressive loss in photosynthesis was found to be co-related with the down regulation of the stomatal conductance and transpiration with enhanced water-use efficiency (Silva et al. 2010), which is an adaptive feature for the plants experiencing drought. Accordingly, the improved intrinsic cellular water-use efficiency that occurs due to loss in transpiration to sustain the hydric status of the plant under drought stress may be related and regulated by an intrinsic mechanism of leaf adjustment during drought (Figure 1C, c).

The maximum quantum yield of PS II photochemistry, as explored through $F \mathrm{v} / F \mathrm{~m}$ analysis (Figure 1D, d) favored optimal retention of fluorescence in plants irrigated up to full field capacity, throughout. Indeed, it is important to assess the functional status of PS II that is found to be affected by drought [i.e. irrigation to the level of half-field capacity in both clones viz., G-48 (37\%) and Kranti (48\%)]. Thus, significant loss in fluorescence values triggered in case these clones irrigated to the level of half field capacity (obeyed Baker et al. 1987), in which increase in minimal fluorescence (Fo) level from darkadapted leaves possibly found, due to reduced plastoquinone acceptor $\left(Q_{A}\right)$, were completely oxidized because of retardation of the electron flow through PS II (Krause and Weis 1991; Velikova et al. 1999). The electron transport rate decreased despite the fact that PS II is highly drought resistant (Yordanov et al. 2003), while the significant loss in maximum quantum yield of PS II photochemistry may be considered as droughtsensitive plant types (Strasser et al. 1995; Percival 2005; Fini et al. 2009; Zlatev and Lidon 2012; Fini et al. 2013). Thus, the significant decline in physiological characteristics as shown by these clones favored them drought susceptible.

The various agronomic traits, such as plant height, number of leaves, leaf area expansion, specific leaf area, relative water content, plant performance, biomass, and harvest index found to be negatively influenced by drought stress as reported in the current study, is similar to Zhang et al. (2004), Xiao et al. (2005), Fini et al. (2013), and Santos et al. (2013). The findings conclude that both clones (i.e., G-48 and Kranti) seemed to be sensitive toward drought stress in the planting year (i.e., during establishment phase). Hence, proper and precision irrigation must be ensured for cottonwood plantation by the farmers/ planting agencies to achieve its optimal establishment, growth development, performance, plant productivity, biomass, and harvest index in subsequent years to sustain agro-socio economy.

Acknowledgments. The authors are grateful to Prof. B.R.K. Gupta, Dean, College of Basic Science and Humanities (CBSH), G.B. Pant University of Agriculture and Technology, Pantnagar, Uttarakhand for kindly providing experimental facilities. Thanks to Professor C.L. Verma, Central Soil Salinity Research Institute, Lucknow for his kind help. UGC, New Delhi is duly acknowledged for providing facilities to MS \{File no. 37-438/2009(SR)\} which supported manuscript submission.

\section{LITERATURE CITED}

Akcay, U., O. Ercan, M. Kavas, I. Yildiz, C. Yilmaz, H.A. Oktem, and M. Yucel. 2010. Drought-induced oxidative damage and antioxidant responses in peanut (Arachis hypogaea L.) seedlings. Plant Growth Regulation 6:21-28.

Baker, B., G. Coupland, N.V. Fedoroff, P. Starlinger, and J. Schell. 1987. Phenotypic assay for excision of the maize controlling element Ac in tobacco. EMBO Journal 6:1547-1554.
Chaves, M.M. 1991. Effects of water deficits on carbon assimilation. Journal of Experimental Botany 42:1-16.

Chen, S., S. Wang, A. Altman, and A. Huttermann. 1997. Genotypic variation in drought tolerance of poplar in relation to abscisic acid. Tree Physiology 17(12):797-803.

Fini, A., C. Bellasio, S. Pollastri, M. Tattini, and F. Ferrini. 2013. Water relations, growth, and leaf gas exchange as affected by water stress in Jatropha curcas. Journal of Arid Environments 89:21-29.

Fini, A., F. Ferrini, P. Frangi, G. Amoroso, and R. Piatti. 2009. Withholding irrigation during the establishment phase affected growth and physiology of Norway maple (Acer platanoides) and Linden (Tilia spp.). Arboriculture \& Urban forestry 35(5):241-251.

Fukuzawa, Y., J. Tominaga, K. Akashi, S. Yabuta, M. Ueno, and Y. Kawamitsu. 2012. Photosynthetic gas exchange characteristics in Jatropha curcas L. Plant Biotechnology 29:155-162.

Johari-Pireivatlou, M., N. Qasimov, and H. Maralian. 2010. Effect of soil water stress on yield and proline content of four wheat lines. African Journal of Biotechnology 9:36-40.

Krause, G.H., and E. Weis. 1991. Chlorophyll fluorescence and photosynthesis: The basics. Annual Review Plant Physiology Plant Molecular Biology 42:313-349.

Lawlor, D.W. 1995. The effects of water deficit on photosynthesis. In: N. Smirnoff (Ed.). Environment and Plant Metabolism. Flexibility and Acclimation. Oxford: BIOS Scientific Publishers.

Levitt, J. 1980. Responses of plants to environmental stresses. In: Water, Radiation, Salt and other stresses. Academic Press, New York, New York, U.S.

Maier, M.U. 1998. Dynamics of change in stomatal response and water status of Picea abies during a persistent drought period: A contribution to the traditional view of plant water relations. Tree Physiology 18:211-222.

Nautiyal, P.C., N.R. Rachaputi, and Y.C. Joshi. 2002. Moisture-deficitinduced changes in leaf-water content, leaf carbon exchange rate and biomass production in groundnut cultivars differing in specific leaf area. Field Crops Research 74:67-79.

Niinemets, U. 2001. Global-scale climatic controls of leaf dry mass per area, density, and thickness in trees and shrubs. Ecology 82:453-469.

Percival, G.C. 2005. The use of chlorophyll fluorescence to identify chemical and environmental stress in leaf tissue of three oak (Quercus) species. Journal of Arboriculture 31(5):215-227.

Poorter, L., and L. Markesteijn, 2008. Seedling traits determine drought tolerance of tropical tree species. Biotropica 40:321-331.

Santos, C.M., V. Verissimo, H.C.L.W. Filho, V.M. Ferreira, P.G.S. Cavalcante, E.V. Rolim, and L. Endres. 2013. Seasonal variations of photosynthesis, gas exchange, quantum efficiency of photosystem II and biochemical responses of Jatropha curcas L. grown in semi-humid and semi-arid areas subject to water stress. Industrial Crops and Products 41:203-213.

Silva, E.N., R.V. Ribeiro, S.L. Ferreira-Silva, R.A. Viegas, and J.A.G. Silveira. 2010. Comparative effects of salinity and water stress on photosynthesis, water relation, and growth of Jatropha curcas plants. Journal of Arid Environments 74:1130-1137.

Singh, M. 1991. Photosynthetic characteristic of Populus deltoides under light and heat stress. Ph.D. Thesis CSIR-NBRI and University of Lucknow, Lucknow.

Singh, M., and R. Chaturvedi. 1997. Molecular mechanism of photoinhibition in higher plants. Agro's Annual Review Plant Physiology 3:122-138.

Singh, M., M. Jain, and R.C. Pant. 1999. Clonal variability in photosynthetic and growth characteristics of Populus deltoides under saline irrigation. Photosynthetica 36(4):605-609. 
Singh, M., R. Chaturvedi, and P.V. Sane. 1996. Diurnal and seasonal photosynthetic characteristics of Populus deltoides Marsh. Leaves. Photosynthatica 32:11-21.

Strasser, R.J., A. Srivastava, and Govindjee. 1995. Polyphasic chlorophyll a fluorescence transient in plants and cyanobacteria. Photochemistry and Photobiology 61:32-42.

Tschaplinski, T.J., A. Gerald, G. Tuskan, M. Gebre, and E.D. Todd. 1998. Drought resistance of two hybrid Populus clones grown in a largescale plantation. Tree Physiology 18(10):653-658.

Velikova, V., T. Tsonev, and I. Yordanov. 1999. Light and $\mathrm{CO}_{2}$ responses of photosynthesis and chlorophyll fluorescence characteristics in bean plants after simulated acid rain. Physiologia Plantarum 107:77-83.

Verma, K.K., S. Vatsal, R.K. Gupta, S. Ranjan, C.L. Verma, and M. Singh. 2012. Influence of water application on photosynthesis, growth, and biomass characteristics in Jatropha curcas. Current Botany 3(4):26-30.

Xiao, CW., G.S. Zhou., X.S. Zhang., J.Z. Zhao, and G. Wu. 2005. Response of dominant desert species Artemisia ordosica and Salix psammophila to water stress. Photosynthetica 43(3):467-471.

Yordanov, I., V. Velikova, and T. Tsonev. 2003. Plant responses to drought and stress tolerance. Bulgarian Journal of Plant Physiology Special Issue 187-206.

Zhang, X., R. Zang, and C. Li. 2004. Population differences in physiological and morphological adaptations of Populous davidiana seedlings in response to progressive drought stress. Plant Science 166:791-797.

Zlatev, Z., and F.C. Lidon. 2012. An overview on drought induced changes in plant growth, water relations, and photosynthesis. Emirates Journal of Food and Agriculture 24(1):57-72.

Zlatev, Z.S., and I. Yordanov. 2004. Effects of soil drought on photosynthesis and chlorophyll fluorescence in bean plants. Bulgarian Journal of Plant Physiology 30(3-4):3-18.

Munna Singh (corresponding author)

Department of Plant Physiology

CBSH, G.B. Pant University of Agriculture and Technology

Pantnagar-263145 (Uttarakhand)

India

Present address:

Department of Botany

University of Lucknow

Lucknow-226007 (U.P.)

India

profmunnasingh@gmail.com

drmunnasingh@yahoo.com

Aradhna Kumari

Department of Plant Physiology

College of Agriculture (sub campus)

Jawaharlal Nehru Krishi Vishwa Vidyalaya, Ganj Basoda,

Vidisha, Madhya Pradesh-464 221

merymetu@gmail.com

Krishan Kumar Verma

Department of Botany

University of Lucknow

Lucknow-226 007 (U.P.)

India

kverma22feb@yahoo.in
Zusammenfassung. Sechs Wochen alte gleichförmige Schwarzpappel-Sämlinge (Klone G-48 und Kranti) wurden als Steckhölzer kultiviert und unter zwei verschiedenen Bewässerungsregimen (volle und halbe Feldkapazität) bis zu 60 Tage bei offenen Feldbedingungen kultiviert. Die höheren und niedrigeren Regulationen der physiologischen Reaktionen wurden durch die unterschiedliche Bewässerung bei voller oder halber Kapazität beeinflusst. Der verstärkte A-Wert wurde beobachtet bei 13-19 und 12-14 $\mu \mathrm{mol} \mathrm{m}-2 \mathrm{~s}-1$ in den Klonen G-48 und Kranti, nachdem sie bei voller Feldkapazität bewässert wurden. Eine Reduzierung der Wassergabe auf den Level von halber Feldkapazität konnte diese Werte $(\leq 50 \%)$ deutlich reduzieren. Die verminderte $\mathrm{CO}_{2}$ Assimilation während des Trockenheitsstress war korreliert mit dem Rückgang an Transpiration, größtenteils beeinflusst durch die Dynamik der Stomata um die $\mathrm{CO}_{2}$ Diffusion zu begrenzen, welches auch die Karboxylation einschloss. Über der Trockenheitserfahrung war der progressive Verlust an Maximum Quantum Ertrag der Photosystem II Photochemie (Fv/ Fm) und $\mathrm{CO}_{2}$ Assimilation korreliert mit dem Verlust an Transpiration bei beiden Klonen. Schlussendlich wurde durch die Studie erwiesen, dass eine Bewässerung bis zur Hälfte der Feldkapazität über einen Zeitraum von 60 Tagen die agronomischen Merkmale, die da wären: Pflanzenhöhe, Anzahl der Blätter, Blattflächenausdehnung, besondere Blattfläche, relativer Wassergehalt, Biomasse und Ernte-Index, deutlich mindert. Es schließt ebenso die Anfälligkeit der Klone G-48 und Kranti gegenüber Trockenheit in Relation zur Pflanzen-Performance (z.B. $\mathrm{CO}_{2}$ Assimilation, $\mathrm{Fv} / \mathrm{Fm}$, und Biomassenertrag) ein.

Resumen. Plántulas de álamo (clones G-48 y Kranti) de seis semanas de edad se plantaron a partir de esquejes de tallo y fueron sometidos a dos regímenes diferentes de agua (capacidad de campo, completa y media) hasta 60 días, bajo condiciones de campo abierto. Se emitieron regulaciones superiores e inferiores con base en las respuestas fisiológicas, para plantas regadas a plena y media capacidad de campo. El valor A mejorado se observó de $13-19$ y $12-14 \mu \mathrm{mol} \mathrm{m}-2 \mathrm{~s}-1$ en los clones G-48 y Kranti, después de someterlos a riego a capacidad de campo completo. La eliminación del riego para el nivel medio de capacidad de campo podría reducir estos valores $(\leq 50 \%)$ de manera significativa. Se encontró que la disminución de la asimilación de $\mathrm{CO}_{2}$ durante el estrés por sequía se correlaciona con la disminución de la transpiración, regulada en gran medida por la dinámica de los estomas para restringir la difusión del $\mathrm{CO}_{2}$, que también deteriora la carboxilación. Al experimentar la sequía, se encontró que la pérdida progresiva en el rendimiento cuántico máximo del fotosistema II fotoquímicamente ( $\mathrm{Fv} / \mathrm{Fm}$ ) y la asimilación de $\mathrm{CO}_{2}$ se correlaciona con la pérdida de la transpiración en estos dos clones. En consecuencia, el estudio revela que el riego al nivel de capacidad de campo durante un período de 60 días, influye significativamente en los rasgos agronómicos a saber, altura de planta, número de hojas, expansión del área foliar, área foliar específica, contenido relativo de agua, biomasa y el índice de cosecha. Asimismo, se concluye la susceptibilidad de los clones G-48 y Kranti hacia la sequía, en relación con el rendimiento de la planta (es decir, la asimilación de $\mathrm{CO}_{2}, \mathrm{Fv} / \mathrm{Fm}$ y rendimiento de biomasa). 